\title{
Gambaran Pengambilan Keputusan Saat Proses Rujukan dari Tingkat Primer ke Tingkat Sekunder di Rumah Sakit Umum Daerah Sumedang
}

\author{
Atikah Putri Wulandari', Ari Indra Susanti², Ariyati Mandiri \\ ${ }^{1}$ Program Diploma Kebidanan, Fakultas Kedokteran Universitas Padjadjaran \\ ${ }^{2}$ Departemen Ilmu Kesehatan Masyarakat, Fakultas Kedokteran Universitas Padjadjaran
}

\begin{abstract}
Abstrak
Sebanyak 85\% ibu hamil atau bersalin mengalami proses normal dan $15 \%$ mengalami komplikasi. Jika ibu bersalin mengalami komplikasi dan tidak segera ditangani akan berdampak terhadap Angka Kematian Ibu (AKI). Penyebab tidak langsung salah satunya 4 Terlambat telah menyumbangkan AKI cukup besar. Salah satu dari 4T tersebut adalah terlambat mengambil keputusan setuju merujuk. Maka dari itu peneliti melakukan penelitian yang bertujuan untuk mengetahui gambaran pengambilan keputusan saat proses rujukan dari tingkat primer ke tingkat sekunder di RSUD Sumedang. Metode yang dilakukan adalah metode deskriptif dengan pendekatan cross sectional. Pengambilan sampel dilakukan dengan teknik accidental sampling. Data diambil dari kuesioner yang dibagikan pada 90 ibu yang dirujuk dari tingkat primer ke tingkat sekunder di RSUD Sumedang pada bulan September-Desember 2015. Hasil penelitian yang didapatkan bahwa pengambilan keputusan yang dipegang oleh keluarga cenderung mengambil keputusan dengan lambat sebesar 16,1\% dan mengalami keterlambatan merujuk sebanyak 17,2\%. Pengambilan keputusan diambil dengan cepat baik penyulit dari ibu sebanyak $57,6 \%$ maupun janin sebanyak $42,4 \%$. Kesimpulan penelitian ini adalah pengambilan keputusan lebih banyak oleh suami, namun pengambilan keputusan oleh keluarga lebih lambat dan mengakibatkan keterlambatan merujuk. Kemudian, pengambilan keputusan pun lebih cepat baik dari penyulit ibu maupun janin
\end{abstract}

Kata Kunci : Keterlambatan merujuk, merujuk, pengambilan keputusan, penyulit,

\section{Decision Making Process Overview of Current Referral Level of Primary to Secondary Level General Hospital in Regional Sumedang}

\begin{abstract}
As many as $85 \%$ of pregnant womens or maternity womens undergo the normal process, and $15 \%$ had complications. If maternal experience complications and not treated immediately will impact on Maternal Mortality Rate (MMR). The indirect causes 4 Late one has donated sizeable AKI. One of these 4T is delayed taking the decision to agree to refer. Thus the researchers conducted a study which aims to describe the current decisionmaking process of referral from the primary level to the secondary level in Sumedang District Hospital. The method used is an descriptif method with cross sectional approach. Sampling was done by accidental sampling technique. Data were taken from questionnaires distributed to 90 pregnant or maternity womens who were referred from the primary level to the secondary level in Sumedang Distric Hospital at September-Desember 2015. The research results showed that the decision held by families tend to make decisions slowly by $16.1 \%$ and delayed referring as much as $17.2 \%$. Decision-making is taken quickly both complications of mother and fetus as much as $57.6 \%$ as much as $42.4 \%$. It is concluded that more decision-making by the husband, but the decision by the family more slowly and result in a delay refer. Then, the decision was faster both mother and fetus complications
\end{abstract}

Keywords: Complications of pregnant, decision making, delays in referring, referring

Korespondensi:

Atikah Putri Wulandari

Program Diploma Kebidanan, Fakultas Kedokteran Universitas Padjadjaran

Jl. Raya Bandung Sumedang KM 21 Jatinangor, Sumedang

Mobile : 085718857456

Email : atikahputriw@gmail.com 


\section{Pendahuluan}

Persalinan merupakan salah satu kejadian besar bagi seorang ibu. Diperlukan segenap kemampuan baik tenaga maupun pikiran guna melalui tahapan prosesnya. Banyak ibu hamil dapat melalui proses persalinan dengan lancar dan selamat. Namun, banyak pula ibu hamil mengalami persalinan dengan komplikasi yang disebabkan oleh berbagai hal. Menurut Endang L. Achadi, 85\% ibu hamil atau bersalin mengalami proses normal dan $15 \%$ mengalami komplikasi. Jika ibu bersalin mengalami komplikasi dan tidak segera ditangani akan berdampak terhadap Angka Kematian Ibu (AKI). ${ }^{1}$ Berdasarkan data WHO pada tahun 2007 , bahwa setiap tahunnya wanita yang bersalin meninggal dunia mencapai lebih dari 536.000 orang per kelahiran hidup. Angka ini disumbang oleh negara-negara yang sedang berkembang salah satunya Indonesia. ${ }^{2}$ Berdasarkan Kemenkes tahun 2012, di kawasan ASEAN (Association of South East Asian Nations) tercatat bahwa Indonesia merupakan negara dengan Angka Kematian Ibu (AKI) yang tertinggi dibandingkan negara-negara ASEAN lainnya seperti Thailand 44 per 100.000 kelahiran hidup, Malaysia 39 per100.000 kelahiran hidup, dan Singapura 6 per 100.000 kelahiran hidup. ${ }^{3}$ Berdasarkan data SDKI, bahwa di Indonesia selama periode tahun 1991-2007 AKI mengalami penurunan dari 390 menjadi 228 per 100.000 kelahiran ibu. Namun pada tahun 2012 AKI kembali naik menjadi 359 per 100.000 kelahiran hidup. Angka tersebut semakin jauh dengan target MDGs 2015 sebesar 102 per 100.000 kelahiran hidup. Berdasarkan data dari Dinas Kesehatan Provinsi Jawa Barat tahun 2012 menunjukan bahwa AKI berjumlah 747 per 100.000 kelahiran hidup dan AKB berjumlah 355 per 1.000 kelahiran hidup.,

Menurut Laporan Direktorat Kesehatan Ibu tahun 2013, penyebab kematian ibu terbanyak masih didominasi perdarahan $(30,3 \%)$, disusul hipertensi dalam kehamilan $(27,1 \%)$, infeksi $(7,3 \%)$, partus lama $(1,8 \%)$, abortus $(1,6 \%)$ serta penyebab lain-lain $(40,8 \%)$ cukup besar, termasuk didalamnya penyebab penyakit non obstetri dan penyebab tidak langsung. Penyebab tidak langsung yaitu empat terlalu (hamil atau bersalin terlalu muda dan tua, terlalu banyak anak, terlalu dekat jarak kehamilan/persalinan) dan tiga terlambat (terlambat dalam pengambilan keputusan, terlambat merujuk, terlambat ditangani di tempat pelayanan karena tidak efektifnya pelayanan di fasilitas kesehatan). ${ }^{5}$

Menurut hasil penelitian bahwa kematian ibu bersalin disebabkan keterlambatan dalam merujuk pasien ke rumah sakit yang terdiri dari keterlambatan dalam mengambil keputusan setuju merujuk dari pihak keluarga disebabkan adat istiadat dan keterlambatan dalam mengenali risiko tinggi ibu bersalin. ${ }^{6}$

Dari hasil penelitian Nurhayati tahun 2007, menyatakan bahwa peran suami mengambil keputusan sangat dominan baik sebelum persalinan maupun saat persalinan. Hal ini menggambarkan bahwa laki-laki sebagai suami lebih mendominasi dalam proses pengambilan keputusan untuk penanganan kehamilan dan persalinan. ${ }^{7}$ Menurut hasil penelitian Sri tahun 2008, menyatakan bahwa kematian ibu bersalin salah satunya disebabkan keterlambatan dalam pengambilan keputusan setuju merujuk dari pihak keluarga. Maka dari itu pengambilan keputusan lebih didominasi oleh keluarga sehingga pengambilan keputusan untuk merujuk menjadi lebih lama yang akhirnya akan dapat berdampak terhadap Angka Kematian Ibu (AKI) dan Angka Kematian Neonatal (AKN). ${ }^{8}$ Pengambilan keputusan seharusnya tidak hanya di tangan suami atau keluarga. Namun, perempuan harus mampu mengambil keputusan untuk menentukan hak kesehatan reproduksi dirinya. Hak reproduksi tersebut salah satunya perempuan memiliki hak otonomi untuk menentukan penanganan persalinan dan komplikasi yang akan dihadapi serta bebas dalam menentukan keputusan rasional untuk bertindak sesuai kebutuhan dan masalah yang dihadapi. Ini karena perempuan juga memiliki hak untuk memperoleh derajat kesehatan yang setinggi-tingginya. Hal ini didukung oleh organisasi kesehatan dunia yaitu World Health Organization yang menyepakati bahwa derajat kesehatan yang setinggi-tingginya adalah suatu hak yang fundamental bagi setiap orang tanpa membedakan ras, agama, politik yang dianut, tingkat sosial ekonomi dan jenis kelamin. ${ }^{9}$

Dengan begitu, pengambilan keputusan menjadi efektif dalam penanganan persalinan dan komplikasi. Dengan dampak pengambilan keputusan yang tepat dan cepat akan mencegah terjadinya keterlambatan. Diantaranya keterlambatan mengenal resiko tinggi dan tanda bahaya pada kehamilan, keterlambatan pengambilan keputusan yang mengakibatkan keterlambatan dalam merujuk, dan mendapatkan pertolongan tenaga kesehatan. Sehingga dapat berdampak pula terhadap penurunan angka kesakitan dan kematian ibu dan neonatal di Indonesia.

Berdasarkan hasil survei awal pada bulan April 2015 didapatkan 20 orang ibu yang mengalami komplikasi obstetri dan dirujuk ke RSUD Sumedang menyatakan bahwa pengambilan keputusan berada di tangan keluarga dan suami. Dan data menunjukkan bahwa pasien yang 
dirujuk dari Bidan ke PONEK RSUD Sumedang pada tahun 2014 berjumlah 2.425 orang dan dari bulan Januari - Mei 2015 berjumlah 881 orang.

Dari latar belakang diatas peneliti tertarik untuk melakukan peneltian berjudul "Gambaran Pengambilan Keputusan Saat Proses Rujukan di Rumah Sakit Umum Daerah Sumedang”.

\section{Metode}

Penelitian ini menggunakan metode deskriptif dengan pendekatan cross-sectional. Data yang diambil berupa data primer yang diambil secara langsung kepada responden dan data sekunder. Pada penelitian ini pengumpulan data dilakukan hanya pada satu waktu selama penelitian dengan pengambilan sampel menggunakan teknik accidental sampling. Populasi pada penelitian ini adalah seluruh ibu yang dirujuk dengan komplikasi obstetri ke RSUD Kabupaten Sumedang sebanyak 881 orang berdasarkan pencatatan terakhir pada bulan Januari-Mei 2015. Sampel dalam penelitian ini adalah ibu yang dirujuk dengan komplikasi obstetri saat persalinan dari unit primer ke unit sekunder sebanyak 90 orang. Kriteria inklusi pada penelitian ini adalah Ibu yang dirujuk ke RSUD Sumedang dan mengalami komplikasi obstetri saat persalinan. Sedangkan kriteria eksklusi adalah Ibu yang dirujuk oleh dokter spesialis ke RSUD Sumedang dan mengalami komplikasi obstetrik dan ibu yang tidak bersedia menjadi responden

\section{Hasil}

Dari tabel 1 dapat diketahui bahwa pengambilan keputusan sebagian besar dipegang oleh suami sebanyak $53,3 \%$ dan cenderung mengambil keputusan secara cepat sebanyak 66,7\%. Sedangkan pengambilan keputusan yang dipegang oleh keluarga cenderung mengambil keputusan dengan lambat sebesar 71,4\%. Dari tabel nomor 2 dapat diketahui bahwa pengambilan keputusan yang dipegang istri cenderung tidak mengalami keterlambatan merujuk sebanyak $100 \%$. Sedangkan pengambilan keputusan oleh keluarga cenderung mengalami keterlambatan merujuk sebanyak $71,4 \%$.

Tabel 1 Distribusi Frekuensi Tabulasi Silang Pengambil Keputusan dan Waktu untuk Mengambil Saat Proses Rujukan dari Tingkat Primer ke Tingkat Sekunder

\begin{tabular}{|c|c|c|c|c|c|c|}
\hline \multirow{3}{*}{$\begin{array}{l}\text { Pengambilan } \\
\text { Keputusan }\end{array}$} & \multicolumn{6}{|c|}{ Waktu untuk Mengambil Keputusan } \\
\hline & \multicolumn{2}{|c|}{ Lambat } & \multicolumn{2}{|c|}{ Cepat } & \multicolumn{2}{|c|}{ Total } \\
\hline & $\mathbf{f}$ & $\%$ & f & $\%$ & $\mathbf{f}$ & $\%$ \\
\hline Keluarga & 5 & 71,4 & 2 & 28,6 & 7 & 7,8 \\
\hline Suami & 16 & 33,3 & 32 & 66,7 & 48 & 53,3 \\
\hline Istri & 2 & 40,0 & 3 & 60,0 & 5 & 5,6 \\
\hline Suami dan Istri & 8 & 26,7 & 22 & 73,3 & 30 & 33,3 \\
\hline Total & 31 & 34,4 & 59 & 65,6 & 90 & 100 \\
\hline
\end{tabular}

Tabel 2 Distribusi Frekuensi Tabulasi Silang Pengambil Keputusan dan Waktu Rujukan dari Tingkat Primer ke Tingkat Sekunder

\begin{tabular}{lcccccc}
\hline $\begin{array}{l}\text { Pengambilan } \\
\text { Keputusan }\end{array}$ & \multicolumn{9}{c}{ Waktu Rujukan } \\
& \cline { 2 - 8 } & \multicolumn{7}{c}{ Terlambat Merujuk } & Tidak Terlambat Merujuk & \multicolumn{2}{c}{ Total } \\
\cline { 2 - 8 } & $\mathbf{f}$ & $\mathbf{\%}$ & $\mathbf{f}$ & $\mathbf{\%}$ & $\mathbf{f}$ & $\mathbf{\%}$ \\
\hline Keluarga & 5 & 71,4 & 2 & 28,6 & 7 & 7,8 \\
Suami & 20 & 41,7 & 28 & 58,3 & 48 & 53,3 \\
Istri & 0 & 0 & 5 & 100 & 5 & 5,6 \\
Suami dan Istri & 4 & 13,3 & 26 & 86,7 & 30 & 33,3 \\
\hline Total & $\mathbf{2 9}$ & $\mathbf{3 2 , 2}$ & $\mathbf{6 1}$ & $\mathbf{6 7 , 8}$ & $\mathbf{9 0}$ & $\mathbf{1 0 0}$ \\
\hline
\end{tabular}


Tabel 3 Distribusi Frekuensi Tabulasi Silang Waktu untuk Mengambil Keputusan dan Waktu Rujukan dari Tingkat Primer ke Tingkat Sekunder

\begin{tabular}{lccccccc}
\hline $\begin{array}{l}\text { Waktu Untuk } \\
\text { Mengambil Keputusan }\end{array}$ & \multicolumn{9}{c}{ Waktu Rujukan } \\
& \cline { 2 - 8 } & \multicolumn{9}{c}{ Terlambat Merujuk } & Tidak Terlambat Merujuk & \multicolumn{2}{c}{ Total } \\
\cline { 2 - 8 } & $\mathbf{f}$ & $\mathbf{\%}$ & $\mathbf{f}$ & $\mathbf{\%}$ & $\mathbf{f}$ & $\mathbf{\%}$ \\
\hline Lambat & 19 & 61,3 & 12 & 38,7 & 31 & 34,4 \\
Cepat & 13 & 22,0 & 46 & 78,0 & 59 & 65,6 \\
\hline Total & $\mathbf{3 2}$ & $\mathbf{3 5 , 6}$ & $\mathbf{5 8}$ & $\mathbf{6 4 , 4}$ & $\mathbf{9 0}$ & $\mathbf{1 0 0}$ \\
\hline
\end{tabular}

Tabel 4 Distribusi Frekuensi Tabulasi Silang Jenis Penyulit dan Waktu untuk Mengambil Keputusan Saat Proses Rujukan dari Tingkat Primer ke Tingkat Sekunder

\begin{tabular}{lccccccc}
\hline Jenis Penyulit & \multicolumn{7}{c}{ Waktu untuk Mengambil Keputusan } \\
\cline { 2 - 8 } & \multicolumn{2}{c}{ Lambat } & \multicolumn{3}{c}{ Cepat } & \multicolumn{3}{c}{ Total } \\
\cline { 2 - 8 } & f & $\mathbf{\%}$ & f & $\mathbf{\%}$ & f & \% \\
\hline Lambat & 19 & 35,8 & 34 & 64,2 & 53 & 58,9 \\
Cepat & 12 & 32,4 & 25 & 67,6 & 37 & 41,1 \\
\hline Total & $\mathbf{3 1}$ & $\mathbf{3 4 , 4}$ & $\mathbf{5 9}$ & $\mathbf{6 5 , 6}$ & $\mathbf{9 0}$ & $\mathbf{1 0 0}$ \\
\hline
\end{tabular}

Tabel 5 Distribusi Frekuensi Tabulasi Silang Jenis Penyulit dan Waktu Rujukan dari Tingkat Primer ke Tingkat Sekunder

\begin{tabular}{lccccccc}
\hline Jenis Penyulit & \multicolumn{6}{c}{ Waktu untuk Mengambil Keputusan } \\
\cline { 2 - 8 } & \multicolumn{2}{c}{ Lambat } & \multicolumn{3}{c}{ Cepat } & \multicolumn{3}{c}{ Total } \\
\cline { 2 - 8 } & f & $\mathbf{\%}$ & f & \% & f & \% \\
\hline Lambat & 19 & 35,8 & 34 & 64,2 & 53 & 58,9 \\
Cepat & 12 & 32,4 & 25 & 67,6 & 37 & 41,1 \\
\hline Total & $\mathbf{3 1}$ & $\mathbf{3 4 , 4}$ & $\mathbf{5 9}$ & $\mathbf{6 5 , 6}$ & $\mathbf{9 0}$ & $\mathbf{1 0 0}$ \\
\hline
\end{tabular}

Dari tabel 3 distribusi frekuensi tabulasi silang waktu untuk mengambil keputusan dan waktu rujukan dari tingkat primer ke tingkat sekunder dapat diketahui bahwa pengambilan keputusan yang lambat cenderung mengalami keterlambatan merujuksebanyak $61,3 \%$, sedangkan pengambilan keputusan yang cepat cenderung mengalami ketidak terlambatan merujuk sebanyak $78,0 \%$. Dari tabel 4 dapat diketahui bahwa pengambilan keputusan cenderung lebih cepat baik dari jenis penyulit ibu $(64,2 \%)$ maupun dari jenis penyulit janin $(67,6 \%)$. Dan dari tabel 5 dapat diketahui bahwa waktu rujukan tidak mengalami keterlambatan merujuk baik dari jenis penyulit ibu $(69,8 \%)$ maupun dari jenis penyulit janin $(56,8 \%)$.

\section{Pembahasan}

Dari hasil penelitian ini ditemukan bahwa pengambilan keputusan lebih dominan dipegang suami, namun keputusan yang diambil cenderung lebih cepat. Menurut penelitian yang dilakukan di Padang, bahwa pengambilan keputusan masih didominasi oleh suami menunjukkan bahwa di masyarakat masih terjadi ketimpangan gender dengan arti adanya perbedaan status dan peran antara perempuan dan laki-laki yang dibentuk oleh masyarakat sesuai dengan nilai budaya yang berlaku dalam periode tertentu, dimana peran istri hanyalah sebagai anggota keluarga bukan sebagai pengambil keputusan. Ini terlihat dari 
hasil penelitian bahwa pengambilan keputusan oleh istri lebih sedikit dibanding dengan yang lain. Namun, pengambilan keputusan oleh istri cenderung lebih cepat. ${ }^{10,11}$

Meskipun begitu, peran aktif suami tetap sangat dibutuhkan karena suami memiliki tanggung jawab atas kehamilan tersebut. Namun, perempuan pun memiliki hak atas kebebasan berpikir dan membuat keputusan tentang kesehatan reproduksi yang bebas diskriminasi, paksaan, dan kekerasan. Maka dari itu, diperlukan kerjasama antara suami dan istri untuk mengambil keputusan. Peran suami yang berbentuk diskusi bersama istri selama kehamilan akan berdampak besar terhadap perencanaan dan pengambilan keputusan selama kehamilan dan persalinan. Ini dapat terlihat dari hasil penelitian yang menunjukkan bahwa pengambilan keputusan bersama antara suami dan istri cenderung lebih cepat. ${ }^{12}$

Hasil lain pada penelitian ini yaitu keputusan yang diambil keluarga cenderung lebih lambat. Menutut penelitian di Cianjur, bahwa keluarga dianggap dapat mengerti permasalahan yang sedang dihadapi oleh ibu. Maka dari itu, masih banyak masyarakat yang menunggu keputusan keluarga sebelum melakukan tindakan. Namun, keputusan tersebut cenderung lambat karena dibutuhkannya waktu untuk berkumpul anggota keluarga sehingga memakan waktu yang cukup lama untuk melakukan musyawarah. ${ }^{13}$

Dari penelitian ini dapat dilihat bahwa keputusan untuk merujuk ibu yang diambil oleh suami lebih banyak tidak menyebabkan keterlambatan rujukan. Hal ini dikarenakan pengambilan keputusan oleh suami cenderung lebih cepat. Penelitian yang dilakukan di Padang juga mengemukakan bahwa pengambilan keputusan masih didominasi oleh suami tidak menyebabkan keterlambatan merujuk. Hal ini memperlihatkan bahwa terjadi pergeseran budaya kearah positif walaupun pada kenyataan masih terdapat ketimpangan gender, dimana istri masih belum memiliki kekuatan untuk mengambil keputusan sendiri atas keadaan yang terjadi pada dirinya. Namun, disisi lain jika istri diberikan kebebasan dalam pengambilan keputusan untuk dirinya sendiri, dapat terlihat dari hasil penelitian ini bahwa keputusan tersebut cenderung tidak mengalami keterlambatan merujuk. ${ }^{10}$

Hasil lain penelitian tersebut ini ditemukan bahwa keputusan yang diambil keluarga cenderung mengalami keterlambatan merujuk dikarenakan keluarga mengambil keputusan cenderung lambat karena dibutuhkannya diskusi yang cukup lama. Berdasarkan penelitian yang dilakukan di Cianjur, bahwa pengaruh keluarga dalam pengambilan keputusan tanpa dibekali pengetahuan dengan baik tentang rujukan dan komplikasi kehamilan maupun persalinan dan direncanakan semenjak kehamilan akan mengganggu proses pengambilan secara cepat dan tepat untuk merujuk ibu. ${ }^{13}$

Namun, disisi lain jika suami istri bekerja sama dalam pengambilan keputusan maka dapat terlihat dari hasil penelitian ini bahwa tidak terjadinya keterlambatan merujuk yang dikarenakan keputusan diambil dengan cepat. Maka dari itu, diperlukan peran aktif antara suami dan istri selama kehamilan, misalnya suami istri bersamasama melakukan pemeriksaan kehamilan ke bidan untuk mendapatkan informasi seputar kehamilan ibu saat ini dan mampu mendeteksi dini komplikasi sehingga pengambilan keputusan sudah terencana sejak jauh hari.

Dari hasil penelitian ini ditemukan bahwa keputusan yang diambil secara lambat cenderung mengalami keterlambatan rujukan dan begitupula sebaliknya. Penyebab keterlambatan merujuk salah satunya adalah keterlambatan mengambil keputusan untuk merujuk karena perlu mendapat restu suami, keluarga, ataupun pemuka masyarakat serta kurangnya pengertian kesejajaran antara pria dan wanita. Ini sesuai dengan penelitian, bahwa pengambilan keputusan yang diambil oleh keluarga cenderung lebih lambat karena proses tersebut membutuhkan waktu untuk berkumpul bersama dan berdiskusi, sehingga terjadilah keterlambatan merujuk dan pada akhirnya terjadi pula keterlambatan diberikan pertolongan di fasilitas rujukan. ${ }^{14}$

Menurut penelitian yang dilakukan di Cianjur, menyatakan bahwa banyak faktor yang dapat menyebabkan keterlambatan mengambil keputusan yang berakibat terjadinya keterlambatan merujuk, diantaranya adalah kurangnya pengetahuan suami atau keluarga mengenai kehamilan ibu yang sebenarnya serta kurangnya peran suami atau keluarga dalam mendampingi pemeriksaan kehamilan. Dengan begitu, suami dan orang terdekat ibu belum memahami secara maksimal mengenai komplikasi yang dialami oleh ibu. Semua ini akan mempengaruhi pengambilan keputusan saat rujukan. ${ }^{13}$

Seperti hasil lain dari penelitian ini terlihat bahwa dari faktor pendidikan suami ditemukan pendidikan SD sebanyak 35.6\%, SMP sebanyak $23.6 \%$, SMA sebanyak 27.3\%, dan Perguruan Tinggi sebanyak $11.1 \%$. Hal ini menunjukkan adanya faktor lain yang dapat menyebabkan keterlambatan pengambilan keputusan yang mempengaruhi ketelambatan merujuk.

Dari penelitian ini dapat telihat bahwa jenis penyulit lebih banyak dari ibu. Kemudian baik penyulit dari ibu maupun janin cenderung cepat 
pengambilan keputusannya untuk dilakukannya rujukan. Sebenarnya baik penyulit dari ibu ataupun janin membutuhkan penanganan yang cepat dan karena komplikasi yang akan terjadi sama besarnya dan bahayanya. Menurut teori, bahwa rujukan harus dilakukan pada keadaan ibu dan janin masih baik dan rujukan yang dilakukan seharusnya pada saat kehamilan bukan saat persalinan sehingga rujukan akan lebih cepat dan tepat serta tujuan sistem rujukan tercapai. ${ }^{15,16}$

Maka dari itu, apabila dapat mengetahui komplikasi sejak dini akan mempercepat pengambilan keputusan dan penanganan dengan cepat. Untuk mendeteksi dini komplikasi tersebut diperlukan peran aktif dari ibu untuk kunjungan kehamilan minimal 4 kali. Dengan mengikut sertakan suami atau keluarga setiap kali kunjungan maka ibu dan orang terdekat dapat mengetahui apa yang terjadi dengan ibu dan mulai mendiskusikan sejak dini hal-hal yang diperlukan untuk menghadapi komplikasi apabila terjadi. Dengan begitu, pengambilan keputusan lebih cepat dan keputusan yang diambil akan matang karena sudah dibicarakan sejak dini.

Dari penelitian ini dapat telihat bahwa jenis penyulit baik dari ibu maupun janin cenderung cepat dalam pengambilan keputusan sehingga cenderung pula tidak mengalami keterlambatan merujuk. Dengan begitu, diperlukan peran aktif dari orang terdekat ibu untuk mengetahui komplikasi sejak dini. Peran aktif tersebut dapat diwujudkan dengan cara program siaga dengan tujuan perencanaan penanganan persalinan dan komplikasi yang kemungkinan terjadi. Hal ini bertujuan agar tidak terjadi keterlambatan dalam penanganan kasus komplikasi, salah satunya keterlambatan dalam pengambilan keputusan yang berakibat pada keterlambatan merujuk. Maka dari itu, diperlukan sistem rujukan yang terencana secara dini dan tepat waktu. ${ }^{15,17}$

Simpulan pada penelitian ini pengambilan keputusan lebih banyak diambil oleh suami, namun keputusan tersebut cenderung diambil dengan cepat $(66,7 \%)$. Pengambilan keputusan lebih sedikit diambil oleh istri dan keputusan cenderung diambil dengan cepat $(60,0 \%)$. Hal ini menunjukkan masih adanya kesenjangan gender dalam pengambilan keputusan. Sedangkan keputusan yang diambil oleh keluarga cenderung lebih lambat (71,42\%) yang dapat dikarenakan diperlukannya diskusi keluarga yang membutuhkan waktu yang lama. Disisi lain, keputusan yang diambil bersama antara suami dan istri cenderung lebih cepat $(73,33 \%)$. Pengambilan keputusan oleh istri tidak mengalami keterlambatan merujuk (100\%). Begitupula pengambilan keputusan oleh suami $(45,9 \%)$ dan keputusan bersama antara suami dan istri $(86,6 \%)$ cenderung tidak mengalami keterlambatan merujuk. Namun, keputusan yang diambil oleh keluarga cenderung mengalami keterlambatan merujuk $(71,42 \%)$. Keputusan yang diambil secara lambat cenderung mengalami keterlambatan merujuk (61,3\%). Begitupula sebaliknya, keputusan yang diambil dengan cepat cenderung tidak mengalami keterlambatan merujuk (77,9\%). Keputusan yang diambil cenderung lebih cepat, baik dari jenis penyulit ibu (57,6\%) maupun dari jenis penyulit janin $(42,4 \%)$. Baik dari jenis penyulit ibu $(63,8 \%)$ maupun janin $(36,2 \%)$ cenderung tidak mengalami keterlambatan merujuk.

Saran untuk penelitian ini adalah diharapkan bidan dapat meningkatkan kinerja tim penanganan komplikasi obstetrik sesuai dengan SOP. Selain itu juga dapat meningkatkan kemampuan konseling dengan teknik persuasif petugas kesehatan agar penyampaian informasi mudah dipahami sehingga ibu dan keluarga bisa segera mengambil keputusan. Bidan memfasilitasi kepengurusan BPJS agar tidak ada lagi keluhan dari segi biaya untuk dilakukannya rujukan. Peningkatan program $\mathrm{P} 4 \mathrm{~K}$ oleh bidan desa dalam rangka meningkatkan peran aktif suami, keluarga dan masyarakat dalam merencanakan persalinan yang aman dan persiapan dalam menghadapi kemungkinan terjadinya komplikasi ibu. Untuk peneliti selanjutnya diharapkan dapat mempertimbangkan faktor-faktor lain yang menyebabkan keterlambatan merujuk selain dari faktor terlambat dalam pengambilan keputusan.

Keterbatasan penelitian ini adalah sulitnya mengkaji informasi mengenai rujukan yang klien sudah alami dikarenakan pertanyaan yang terdapat di dalam kuesioner yang disebarkan memerlukan flashback dari peristiwa yang telah terjadi sebelumnya.

\section{Daftar Pustaka}

1. Badan Pusat Statistik. Survei Demografi dan Kesehatan Indonesia (SDKI). Jakarta: Badan Pusat Statistik, 2013.

2. Kemenkes. Profil kesehatan Indonesia 2012. Jakarta : Kementrian Kesehatan Republik Indonesia, 2012.

3. Dinkes. 2012. Diaskes pada tanggal 9 Mei 2015

4. Departemen Kesehatan RI. Direktorat Jendral Bina Kesehatan. Buku Kesehatan Ibu dan Anak. Jakarta. : Depkes, 2014.

5. Latuamury, Siti Rabiah. Hubungan Antara Keterlambatan Merujuk dengan Kematian Ibu di RSUD Tidar Kota Magelang Propinsi Jawa Tengah. Tesis. Universitas Gadjah 
Mada. Yogyakarta, 2001.

6. Nurhayati. Peran Gender dalam Pengambilan Keputusan Pelayanan Kebidanan pada persalinan Multigravida di Rumah Bersalin Sari Simpang Limun Medan Januari-Februari 2008. Medan. Karya Ilmiah. Program D IV Bidan Pendidik Fakultas Kedokteran Universitas Sumatra Utara, 2008.

7. Astuti, Sri Puji.Pola Pengambilan KeputusanKeluarga dan Bidan Dalam Merujuk Ibu Bersalin ke Rumah Sakit pada Kasus Kematian Ibu di Kabupaten Demak. Tesis. Program Pasca SarjanIlmu Kesehatan Masyarakat. Universitas Diponegoro. Semarang, 2008.

8. WHO, 2012 www.who.int/gender diunduh pada tanggal 4 Mei 2015 pukul 10.00 WIB

9. Setiadi, Nugroho J. Perilaku Konsumen : Konsep dan Implikasi untuk Strategi dan Penelitian Pemasaran. Kencana. Bogor, 2003.

10. Depkes. Sistem Kesehatan Nasional. Jakarta : Departemen Kesehatan Republik Indonesia, 2009.

11. Notoatmodjo, Soekidjo. Promosi Kesehatan dan Ilmu Perilaku. Jakarta : Rineka Cipta, 2007.

12. Amiruddin, Mariana. Kesehatan dan Hak Reproduksi Perempuan. Diterbitkan atas kerjasama Yayasan Jurnal Perempuan dan
Japan Foundation Indonesia, 2003.

13. Rahmawati, Lisa. Hubungan Pengambil Keputusan Keluarga dan Pengetahuan Ibu Tentang Tanda Bahaya Kehamilan dengan Keterlambatan Rujukan. Skripsi. Program Diploma IV Kebidanan. Politeknik Kesehatan Kemenkes Padang. Padang, 2013.

14. Sadiah, Hani. Kajian Pengambilan Keputusan Dalam Proses Rujukan Ibu dengan Komplikasi Obstetri saat Persalinan di RSSIB Cianjur tahun 2012. Skripsi. Program Sarjana Kesehatan Masyarakat. Universitas Indonesia. Depok, 2012.

15. Manuaba, Ida Bagus. Ilmu Kebidanan Penyakit Kandungan dan Keluarga Berencana Untuk Pendidikan Bidan. Jakarta: EGC, 2001.

16. Manuaba IBG, Rochjati P, Martaadisoebrata D. Bunga rampai obstetri dan ginekologi sosial. Jakarta : PT. Bina Pustaka Sarwono Prawirohardjo, 2011.

17. Bossyns P, Abache R, Abdoulaye MS, Miye M, Depoorter AM, Lerberge WV. Monitoring the referral system through benchmarking in rural Niger:An evaluation of functional relation between health centers and the district hospital. BMC Health Service Research, 2006. 